
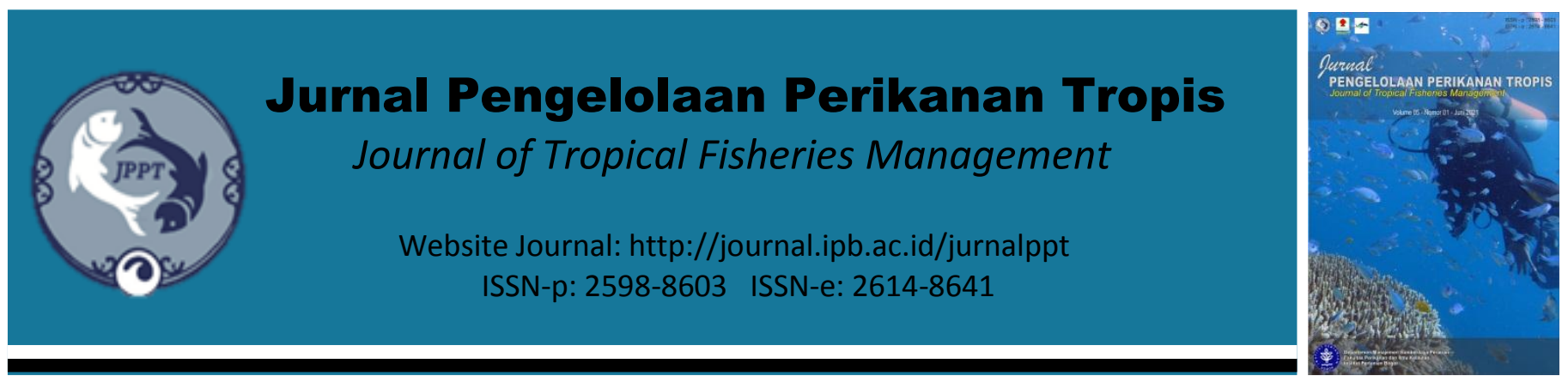

\title{
Identifikasi dan Prevalensi Ektoparasit Ikan Kerapu Lumpur (Epinephelus coioides) Pada Keramba Jaring Apung Di Kuala Langsa
}

\author{
(Identification and Prevalence Ectoparacite of Orange-spotted Grouper (Epinephelus Coioides) On \\ Floating Net Cages In Kuala Langsa)
}

\section{Asha Annur ${ }^{1}$, Suri Purnama Febri ${ }^{1}{ }^{*}$, Muhammad Syahril ${ }^{2}$}

${ }^{1}$ Program Studi Akuakultur Fakultas Pertanian Universitas Samudra, Langsa, Aceh

${ }^{2}$ Program Studi Agroteknologi Fakultas Pertanian Universitas Samudra, Langsa, Aceh

\section{INFO ARTIKEL}

\section{Histori Artikel}

Recevied: 13 Februari 2021

Accepted: 7 Mei 2021

\section{Kata Kunci:}

ektoparasit, identifikasi, kerapu lumpur (Epinephelus coioides),

keramba jaring apung, Kuala Langsa, Prevalensi

\section{Keywords:}

ectoparasite, floating net cages, identification, Kuala Langsa, orange-spotted grouper

(Epinephelus coioides), Prevalence

\section{Korespondensi Author}

Suri Purnama Febri, Program Studi Akuakultur, Fakultas Pertanian, Universitas Samudra

Email:

suripurnamafebri@unsam.ac.id

\begin{abstract}
ABSTRAK
Ikan kerapu lumpur (Epinephelus coioides) merupakan salah satu jenis ikan laut yang bernilai ekonomis serta dapat dikembangkan menjadi komoditas budidaya yang menjanjikan. Tujuan penelitian ini untuk mengetahui jenis-jenis parasit dan tingkat prevalensi ektoparasit pada ikan kerapu lumpur (Epinephelus coioides) pada keramba jaring apung (KJA) di Kuala Langsa. Metode penelitian dilakukan menggunakan metode survei. Sampel diambil berjumlah 20 ekor ikan kerapu lumpur (Epinephelus coioides) yang memiliki ukuran 20$25 \mathrm{~cm}$ dan diamati di Laboratorium Fakultas Pertanian, Universitas Samudra. Organ tubuh ikan diamati meliputi semua bagian sirip, lendir, insang, lalu identifikasi menggunakan cara metode mikroskopis dan makroskopis. Hasil yang diperoleh, ektoparasit yang menginfeksi ikan kerapu lumpur (Epinephelus coioides) hanya satu spesies dari genus Dactylogyrus yang banyak ditemukan pada KJA di Kuala Langsa. Ektoparasit ini ditemukan pada lamella insang ikan kerapu lumpur (Epinephelus coioides), dengan sampel keseluruhan tingkat prevalensi pada $50 \%$ dan tingkat serangannya tergolong dalam sangat sering.
\end{abstract}

\section{ABSTRACT}

Greasy grouper (Epinephelustauvina) is one type of marine fish that has economic value and can be developed into a promising cultivation commodity. The purpose of this research is to find Types of parasites and prevalence rates of ectoparasite in Greasy grouper (Epinephelustauvina) on floating net cages in Kuala Langsa. The research method was conducted using a survey method. Sample taken by purposive sampling, amounting to 20 Greasy grouper (Epinephelustauvina) with a size of $20-25 \mathrm{~cm}$ and were observed at Laboratory Faculty of Agriculture, Samudra University. Fish body organs were observed including all parts of the fins, mucus, gills, then identification using microscopic and macroscopic methods. The results obtained were ectoparasites infecting Greasy grouper (Epinephelustauvina)only one species from the genus Dactylogyrus which was found mostly in floating net cages cultivation in Kuala Langsa.These ectoparasite were found in the gill lamella Greasy grouper (Epinephelustauvina), with the overall sample prevalence rate at $50 \%$ and the attack rate classified as "very frequent".

\section{PENDAHULUAN}

Potensi budidaya laut mempunyai prospek yang sangat baik untuk dikembangkan karena kegiatan ini berperan dalam hal pelestarian sumber daya ikan laut yang mulai langka, yang memenuhi kebutuhan protein hewani, peningkatan penghasilan serta penyediaan lapangan kerja bagi masyarakat. Kegiatan budidaya ikan laut di
Indonesia khususnya ikan kerapu merupakan aktivitas yang relatif baru dan pengembangannya masih perlu di tata dengan baik. Ikan kerapu lumpur (Epinephelus coioides) merupakan salah satu jenis ikan laut yang bernilai ekonomis serta dapat dikembangkan menjadi komoditas budidaya yang menjanjikan. Ikan Kerapu adalah ikan karang yang memiliki nilai ekonomis tinggi dan 
telah menjadi komoditas ekspor penting terutama ke Hongkong, Jepang, Singapura dan Cina (Made 2017).

Budidaya ikan kerapu lumpur yang sudah dilakukan adalah budidaya di keramba jaring apung (KJA). Faktor yang sangat penting dalam menunjang kelangsungan hidup ikan kerapu lumpur yang dibudidayakan salah satunya adalah lingkungan perairan yang tertata dengan baik. Seiring berkembangnya usaha budidaya ikan di keramba jaring apung laut terdapat pula beberapa masalah yang sering mengganggu, sehingga menghambat perkembangan usaha tersebut seperti penyakit yang disebabkan oleh parasit (Bunga 2008). Hendra et al. (2013) menyatakan bahwa parasit yang menyerang ikan kerapu adalah, Benedenia epinephenlis, Caligus epinephelis, Ergasilus, diplectanum grouper, Dactylogyrus, Neobedenia, Gitellae, Haliotrema epinepheli, Pseudorhabdosynochus seobasi, dan Trichordina.

Handayani dan Bambang (1999) dalam Fidyandini (2012) menyatakan bahwa meskipun kejadian penyakit yang disebabkan oleh parasit relatif lebih rendah jika dibandingkan dengan yang disebabkan oleh bakteri dan virus. Namun kasus dari parasit ini tidak dapat diabaikan begitu saja karena infeksi yang disebabkan oleh parasit dapat menyebabkan infeksi primer. Infeksi primer ini dapat mengakibatkan kondisi ikan yang menjadi lemah akibat serangan parasit dan akan memudahkan masuknya mikroorganisme lain yang tentu akan memperparah kondisi ikan dan mempercepat terjadinya kematian.

Mengingat efek parasit teerhadap ikan (sebagai inang) dapat menurunkan nilai produksi dan mutu ikan akibat cacat serta dapat pula membahayakan kesehatan manusia, maka perlu kiranya dapat dilakukan identifikasi. Idenfikasi penyakit berfungsi sebagai alat bantu dalam upaya penanggulangan parasit yaitu dengan melihat jenis-jenis parasit, dan tingkat penyerangan suatu parasit dalam satu populasi ikan yang ditentukan dengan prevalensi. Selain itu pula dengan adanya identifkasi dan prevalensi Ektoparasit yang menyerang ikan akan mempermudah pembudidaya dalam pengendalian atau penanganan parasit itu sendiri agar tidak membahayakan dan merugikan organisme budidaya.

\section{METODE}

\section{Waktu dan Tempat}

Pengambilan sampel ikan Kerapu lumpur dilakukan di keramba jaring apung Kuala Langsa. Pembedahan dan pemeriksaan sampel ikan kerapu lumpur dan identifikasi ektoparasit dilakukan di Laboratorium Dasar Fakultas Pertanian, Universitas Samudra Langsa, pada bulan November 2020.

\section{Pelaksanaan Penelitian}

a. Persiapan alat dan bahan

Persiapan yang dilakukan adalah melakukan sterilisasi gunting, pinset, pisau bedah dan nampan sebelum digunakan, yaitu mencuci hingga bersih alat tersebut menggunakan aquadesh kemudian dikeringkan dengan tissue. Selanjutnya mempersiapkan ikan sampel yang akan diamati.

b. Pengambilan sampel

Cara pengambilan sampel ikan Kerapu Lumpur (Epinephelus coioides) ditentukan dengan metode purposive sampling. Pengambilan sampel dalam penelitian ini dilakukan di dua petakan KJA kuala langsa dengan populasi setiap per petakan 100 ekor dengan ukuran petakan $3 \times 3 \times 3 \mathrm{~m}$, perhitungan jumlah sampel ikan kerapu lumpur yang diambil mengacu pada Stasiun Karantina Ikan Kelas I Hang Nadim Batam (2010) 10\% dari populasi setiap perpetakannya ialah 10 ekor perpetakan dengan keseluruhan sampel 20 ekor ikan Kerapu Lumpur.

Metode pengambilan sampel di keramba dilakukan dengan mengangkat jaring pada petakan dengan menggunakan bambu kemudian mengambil ikan kerapu lumpur yang berdasarkan dengan kriteria tertentu (gejala klinis) sebanyak 20ekor selama 3 kali pengambilan sampel dengan pengukuran panjang ikan kerapu lumpur didapatkan berkisar antara $20-25 \mathrm{~cm}$ dengan menggunakan seser. kemudian di packing dan dibawa ke laboraturium dasar fakultas pertanian untuk dilakukan pengamatan dan pemeriksaan di bawah Mikroskop dan proses identifikasi dengan berdasarkan Buku Saku Pengendalian Hama dan Penyakit Ikan (Dierectorat Kawasan dan Kesehatan ikan (2018) dan Parasites and Disease of Fish (Kabata 1985).

\section{c. Pemeriksaan sampel}

Pemeriksaan sampel dalam penelitian ini dimulai dengan melumpuhkan saraf ikan yang masih hidup dengan scapel dan jarum kemudian memeriksa tubuh bagian luar tubuh ikan yaitu, sirip, lendir dan insang. Pemeriksaan ektoparasit dilakukan dengan cara segar baik secara makroskopis dan mikroskopis dilakukan perbesaran 4x dan 10x. Metode pemeriksaan secara mikroskopis dengan bantuan mikroskop. Prosedur pemeriksaan ektoparasit dilakukan menurut Fernando et al. (1972). 


\section{Pemeriksaan pada Lendir}

Untuk pemeriksaan parasit pada lendir dimulai dengan pengerokan (scrapping) pada permukaan tubuh ikan. Hasil kerokan diletakkan diatas gelas objek dan diberi sedikit air media ikan, kemudian dilakukan pengamatan dibawah mikroskop dengan pembesaran 4 dan 10 kali.

\section{Pemeriksaan pada Sirip}

Untuk pemeriksaan parasit pada sirip dilakukan pada sirip pungung, sirip dada, sirip perut, sirip anal, dan sirip ekor dengan menggunting sirip ikan dan meletakkannya di cawan petri yang telah diberi air media ikan. Preparat kemudian diletakkan diatas gelas objek kemudian dilakukan pengamatan dibawah mikroskop dengan pembesaran 4 dan 10 kali.

\section{Pemeriksaan pada Insang}

Untuk pemeriksaan parasit pada insang dilakukan dengan menggunting operkulum agar lembar-lembar insang dapat terlihat, kemudian dilakukan scarpping pada lamella insang lalu meletakkannya diatas gelas objek yang telah diberi air media ikan, kemudian dilakukan pengamatan dibawah mikroskop dengan pembesaran 4 dan 10 kali.

\section{Parameter penelitian}

Parameter utama yang diamati dalam penelitian ini adalah jenis dan prevalensi ektoparasit yang menyerang ikan Kerapu Lumpur. Parameter penunjang penelitian ini berupa Kualitas air yang meliputi salinitas, suhu, oksigen terlarut, dan $\mathrm{pH}$ diukur dengan alat multichecker selama penelitian.

\section{Analisis data}

Data ektoparasit yang ditemukan dari hasil pemeriksaan sampel kemudian dianalisis secara deskriptif kemudian dihitung persentase ikan yang terinfeksi dari jumlah popilasi ikan pada waktu tertentu (Karantina Ikan Kelas I Hang Nadim, 2010). Dan untuk mengetahui tingkat ikan yang terinfeksi serangan parasit pada ikan dapat dianalisis dengan menghitung Prevalensi menurut (Fernando et al. (2001). Data hasil penelitian akan disajikan dalam bentuk gambar dan tabel.

Keterangan :

$$
\mathrm{P}=\frac{\mathrm{N}}{\mathrm{n}} \mathrm{X} 100 \%
$$

$$
\begin{aligned}
& \mathrm{P} \\
& \mathrm{N} \\
& \mathrm{n}
\end{aligned}
$$

Tingkat prevalensi mengacu kepada Wiliam and Bunkley (1996) disajikan pada Tabel 1.

\section{HASIL DAN PEMBAHASAN}

\section{Hasil}

\section{Identifikasi Ektoparasit}

Berdasarkan hasil identifikasi terhadap 20 sampel ikan kerapu lumpur pada Keramba jaring apung (KJA) diperoleh hanya satu spesies cacing ektoparasit yaitu Dactylogyrus sp. yang ditemukan pada insang dari tujuh sampel ikan dari petakan pertama KJA. Sedangkan pada petakan kedua KJA ditemukan tiga sampel ikan kerapu lumpur yang terinfeksi cacing tersebut.

Tabel 1. Kriteria tingkat prevalensi infeksi parasit

\begin{tabular}{clcc}
\hline No. & Tingkat serangan & Keterangan & Prevalensi \\
\hline 1. & Selalu & Infeksi sangat parah & $100-99 \%$ \\
\hline 2. & Hampir selalu & Infeksi parah & $98-90 \%$ \\
\hline 3. & Biasanya & Infeksi sedang & $89-70 \%$ \\
\hline 4. & Sangat sering & Infeksi sangat sering & $69-50 \%$ \\
\hline 5. & Umumnya & Infeksi biasa & $49-30 \%$ \\
\hline 6. & Sering & Infeksi sering & $29-10 \%$ \\
\hline 7. & Kadang & Infeksi kadang & $9-1 \%$ \\
\hline 8. & Jarang & Infeksi jarang & $>1-0,1 \%$ \\
\hline 9. & Sangat jarang & Infeksi sangat jarak & $>0,1-0,01 \%$ \\
\hline 10. & Hampir tidak pernah & Infeksi tidak pernah & $>\mathrm{P} 0,01 \%$ \\
\hline
\end{tabular}


Hasil identifikasi ektoparasit dapat dilihat pada Gambar 2.

Selanjutnya penyebaran ektoparasit yang menyerang organ bagian luar ikan kerapu lumpur selama pengamatan yaitu tidak ditemukan adanya ektoparasit pada bagian sirip dan lendir atau dalam kondisi yang bersih. Namun, bagian yang diamati pada organ insang ikan ditemukan adanya satu spesies cacing ektoparasit yaitu Dactylogyrus sp. sebanyak 30 ekor parasit yang ditemukan pada seluruh ikan kerapu lumpur dari dua petakan Keramba Jaring Apung. Hasil identifikasi penyebaran ektoparasit pada tubuh bagian luar ikan kerapu lumpur dapat dilihat pada Tabel 3.

Hasil pengamatan dan identifikasi diperoleh Dactylogyrus sp. yang ditemukan pada sampel menunjukan ciri morfologi yaitu memiliki dua pasang titik mata, dan pada ujung kepalanya terdapat empat buah tonjolan. Parasit ini aktif bergerak seperti cacing yaitu memanjang dan memendekan tubuh pada saat pengamatan. Parasit berbentuk pipih dorsoventral dan simetris bilateral. Dactylogyrus sp. yang ditemukan termasuk kedalam genus Dactylogyrus. Cacing ini termasuk dalam Filum Platyhelminthes, karena memiliki bentuk pipih dan memiliki organ pelekatan pada inang; Kelas Monogenea, karena berbentuk pipih dan fusiform dan merupakan cacing ektoparasit dan memiliki haptor pada bagian posterior yang berfungsi untuk menempel pada inang; Ordo Dacttylogyridea karena jangkar sebagai ciri khasnya (Kabata 1985).
Berdasarkan hasil pengamatan dan identifikasi ektoparasit denagn membandingkan morfologi parasit dengan Buku saku pengendalian hama dan penyakit ikan (direktorat kawasan dan kesehatan ikan (2018) dan Parasites and Disease of Fish (Kabata, 1985). Dactylogyrus Sp dapat dilihat pada Gambar 1. Ektoparasit yang ditemukan di awetkan dengan etanol $70 \%$.

\section{Perhitungan Prevalensi}

Hasil penelitian menunjukkan Prevalensi berbeda antara tiap petakan KJA. Pada petakan pertama ditemukan Dactylogyrus sp. pada tujuh sampel ikan kerapu lumpur dengan tingkat prevalensinya sebesar $70 \%$. petakan kedua ditemukan ektoparasit yang sama yang menginfeksi tiga ekor ikan kerapu lumpur dengan tingkat prevalensi sebesar $30 \%$. Nilai prevalensi tersebut menurut Wiliam and Buckley (1996) secara keseluruhan pada budidaya ikan kerapu lumpur pada KJA di Kuala Langsa yaitu sebesar $50 \%$ dan tergolong kedalam tingkat serangan infeksi "Sangat Sering". Perhitungan prevalensi ektoparasit ikan Kerapu Lumpur dapat dilihat pada Tabel 4.

\section{Kualitas air}

Berdasarkan hasil selama penelitian untuk pengukuran kualitas air ikan kerapu lumpur pada Keramba jarring apung kuala langsa, dapat dilihat pada Tabel 5.

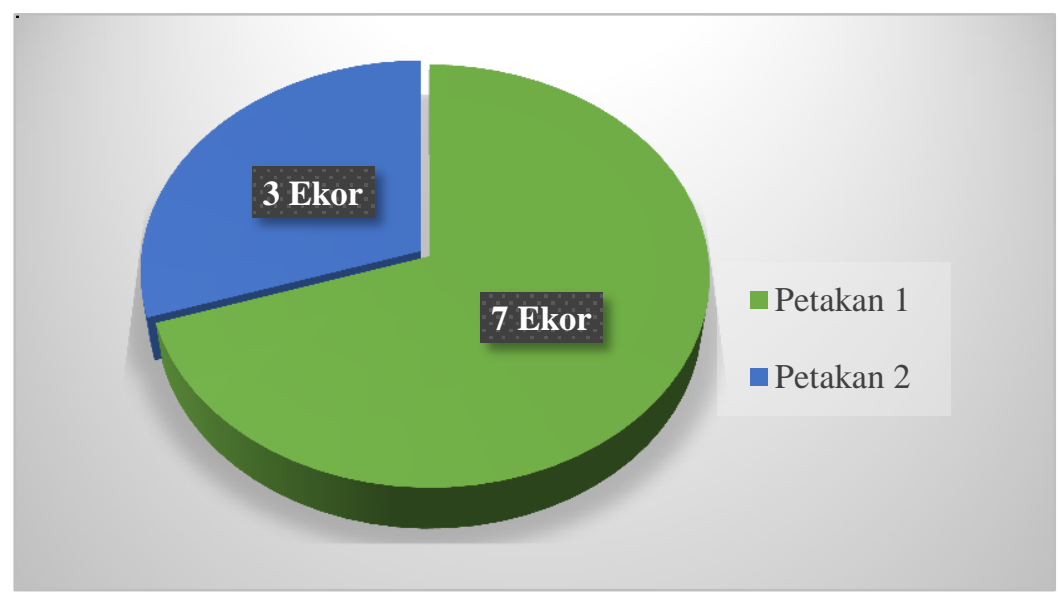

Gambar 1. Hasil identifikasi ektoparasit (Dactylogyrus sp.)

Tabel 3. Penyebaran Ektoparasit pada tubuh bagian luar ikan kerapu lumpur

\begin{tabular}{llllllll}
\hline \multirow{2}{*}{ JenisParasit } & \multicolumn{6}{c}{ Bagiantubuh yang diamati } \\
\cline { 2 - 7 } & D & P & V & D & A & Insang & Lendir \\
\multicolumn{1}{c}{ Dactylogyrus sp. } & - & - & - & - & - & 30 & - \\
\hline Keterangan : \\
$\begin{array}{l}\text { D = Sirip Dorsal (Dada); P = Sirip Pectoral (Perut); V = Sirip Ventral (Pungung); C = Sirip } \\
\text { caudal (Ekor); A = Sirip Anal (Anus) }\end{array}$
\end{tabular}



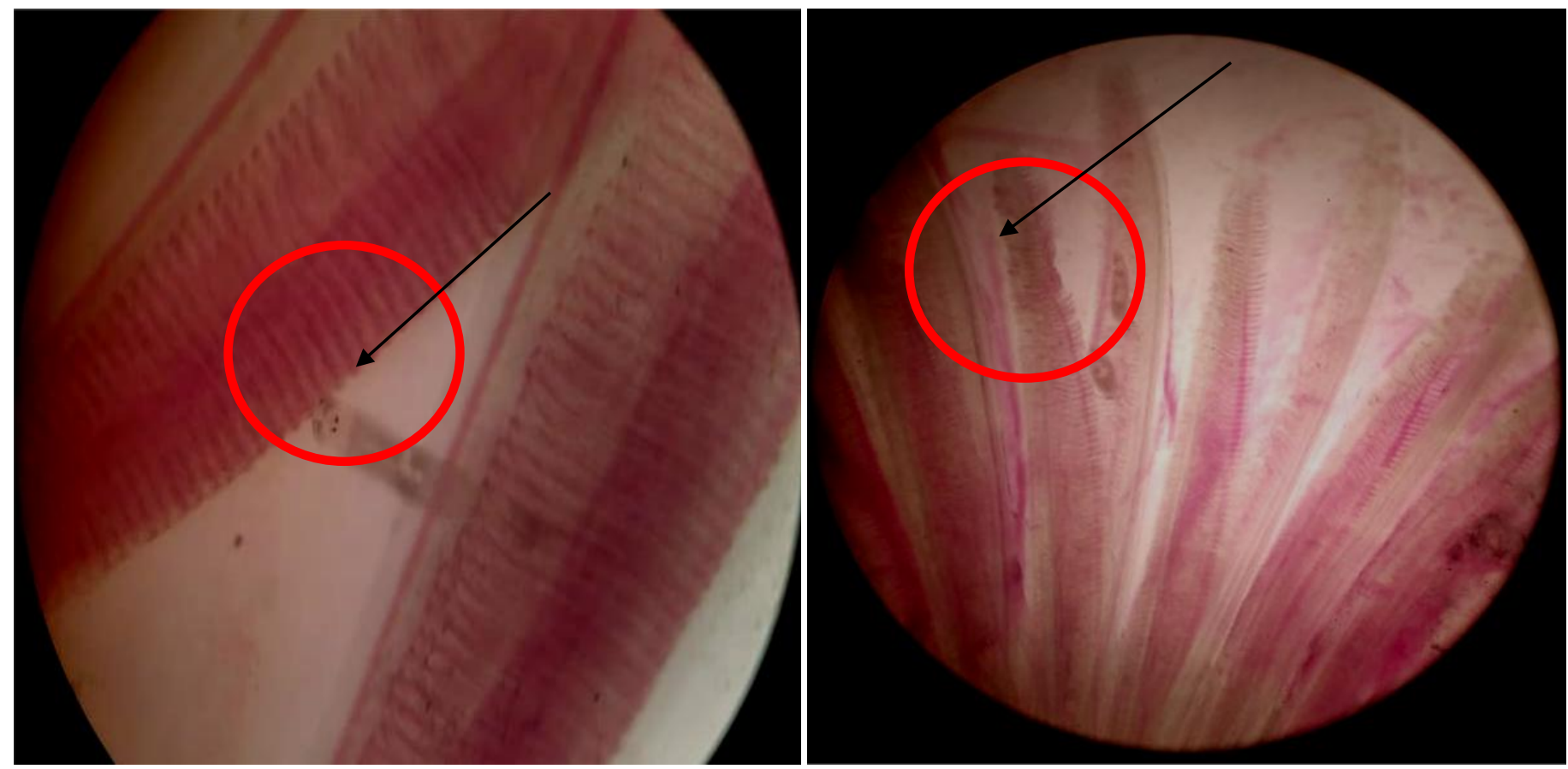

Gambar 1. Dactylogyrus sp.

Tabel 4. Penghitungan prevalensi ektoparasit ikan Kerapu Lumpur

\begin{tabular}{ccccc}
\hline Lokasi & $\begin{array}{c}\text { Jumlahsampel yang } \\
\text { diambil (ekor) }\end{array}$ & $\begin{array}{c}\text { Jumlahikan yang } \\
\text { terinfeksi (ekor) }\end{array}$ & $\begin{array}{c}\text { Tingkat } \\
\text { Prevalensi (\%) }\end{array}$ \\
\hline Petakan KJA I & 10 & 7 & 3 & $70 \%$ \\
Petakan KJA II & 10 & 3 & 7 & $30 \%$ \\
\hline
\end{tabular}

Tabel 5. Data kualitas air

\begin{tabular}{lcc}
\hline Parameter & Petakan KJA I & Petakan KJA II \\
\hline $\mathrm{pH}$ & 6,60 & 6,64 \\
Salinitas (ppt) & 25,6 & 27,3 \\
Do (ppm) & 3,1 & 3,0 \\
Suhu $\left({ }^{0} \mathrm{C}\right)$ & 29,0 & 29,4 \\
\hline
\end{tabular}

\section{Pembahasan}

Identifikasi pada ikan Kerapu Lumpur di Keramba Jaring Apung adalah ditemukannya satu spesies ektoparasit yaitu, cacing Dactylogyrus sp. yang ditemukan pada insang pada tujuh sampel ikan dari petakan pertama Keramba Jaring Apung. Sedangkan pada petakan kedua Keramba Jaring Apung ditemukan tiga sampel ikan Kerapu Lumpur yang terinfeksi cacing tersebut.

Dactylogyrus sp. ektoparasit yang ditemukan termasuk dalam genus Dactylogyrus. Cacing ini termasuk dalam Filum Platyhelminthes karena memiliki bentuk pipih dan memiliki organ pelekatan pada inang (Kabata 1985). Kelas Monogenea karena berbentuk pipih dan fusiform dan merupakan cacing ektoparasit dan memiliki haptor pada bagian posterior yang berfungsi untuk menempel pada inang. Ordo Dacttylogyridea karena jangkar sebagai ciri khasnya (Kabata 1985)
Ektoparasit yang ditemukan pada KJA ini termasuk dalam kelompok parasit obligat. Parasit dalam kelompok ini hanya dapat hidup apabila ada inangnya (Buku saku pengendalian hama dan penyakit ikan, Direktorat kawasan dan kesehatan ikan 2018). Parasit obligat dapat diartikan juga sebagai kelompok parasit yang memang terdapat secara alami diperairan tersebut. Kondisi perairan yang buruk dapat menyebabkan perkembangan parasit menjadi sangat parah dan sulit dikendalikan. Efek yang disebabkan oleh parasit jenis ini adalah filamen insang menonjol keluar dari operculum atau terjadi peregangan pada operculum sehingga terjadi kerusakan berat pada insang. Lendiri atau mucus pada ikan meningkat, mukusa insang berwarna gelap dan menutup insang sehingga insang tampak seperti tertutup lumpur, kulit berwarna gelap menyebabkan bintik 
putih pada kulit, insang dan sirip (Subekti dan Mahasri 2010).

Selanjtnya, hasil penelitian menunjukkan Prevalensi berbeda antara tiap petakan Keramba Jaring Apung. Pada petakan pertama ditemukan Dactylogyrus Sp pada tujuh sampel ikan Kerapu Lumpur dengan Prevalensinya 70\%. Sedangkan pada petakan kedua ditemukan ektoparasit yang sama yang menginfeksi tiga ekor ikan Kerapu Lumpur dengan prevalensi $30 \%$. Nilai prevalensi secara keseluruhan pada budidaya ikan Kerapu Lumpur di Keramba Jaring Apung Kuala Langsa yaitu sebesar 50\% dan menurut Wiliam and Buckley (1996) bahwa tingkat serangannya tergolong dalam kategori Sangat Sering.

Prevalensi terbesar didapat pada petakan keramba jaring apung yang pertama, hal ini dapat dikarenakan posisi letak petakan yang pertama ini lebih dekat dengan bibir sungai dan manajemen pemeliharaan ikan yang kurang baik yaitu kurang memperhatikannya jaring yang digunakan dalam proses budidaya sudah lama, hal ini jelas terlihat dari banyaknya teritip (kerang) yang menempel pada jaring bisa memicu menjadi carier cacing ektoparasit pada ikan.

Keberadaan parasit juga bisa diketahui dari telur yang mereka lepas. Telur parasit cacing insang berbentuk agak lonjong dengan filament yang panjang. Dengan bantuan filament ini telur bisa menempel pada substrat yang terdapat di lingkungan budidaya. Setelah sekitar 5 hari maka telur akan menetas dan menghasilkan larva parasit onchomiracidia yang aktif berenang dengan bantuan cilia mencari inang baru dan menempel pada insang ikan inang menjadi parasit. Sehingga penyebaran ektoparsit ini lebih cepat pada KJA pertama ikan kerapu lumpur dibanding dengan petakan KJA yang kedua yang jaring yang digunakan masih baru dan bersih atau dalam kategori aman dan dikarenakan jarak antar petakan pertama dan kedua itu berjarak 3 meter dapat diartikan bahwa penyebaran ektoparasit ini lebih cepat pada petakan pertama.

Hasil pengukuran kualitas air selama penelitian ialah dapat dilihat pada tabel 5 namun data kualitas air untuk oksigen terlarut ini dengan DO $(3,0-3,1 \mathrm{mg} / \mathrm{L})$ dari dua petakan keramba jaring apung ini rendah sehingga ikan akan mengalami stres ini sesuai dengan Ghufran et al. (2007) ikan kerapu lumpur dapat hidup pada kondisi perairan dengan konsentrasi dibawah $4 \mathrm{mg} / \mathrm{L}$ akan tetapi nafsu makan ikan mulai menurun. Sehingga terjadinya hubungan yang tidak seimbang antara ikan, lingkungan dan pathogen. Hal ini akan menyebabkan ikan mudah terinfeksi oleh ektoparasit.

Menurut laporan Anonymous (2001) bahwa pertumbuhan dan kelangsungan hidup yang baik suhu berkisar antara $25-32^{\circ} \mathrm{C}$, salinitas berkisar antara 20-32 ppt, oksigen terlarut berkisar 4-8 $\mathrm{mg} / \mathrm{L}$ dan $\mathrm{pH}$ berkisar 7,5-8,3. Secara keseluruhan data kualitas air masih dalam batas ambang untuk budidaya ikan kerapu lumpur pada keramba jaring apung kuala langsa.

\section{KESIMPULAN DAN SARAN}

\section{Kesimpulan}

a. Ektoparasit yang ditemukan pada insang ikan Kerapu Lumpur di Keramba Jaring Apung Kuala Langsa adalah Dactylogyrus Sp (Monogenea: Diplectanidae)

b. Prevalensi ektoparsit pada ikan Kerapu Lumpur pada petakan pertama Keramba Jaring Apung Kuala Langsa yaitu :70\% tingkat serangannya tergolong tingkat serangan Biasanya atau Infeksi Sedang

c. Prevalensi ektoparsit pada ikan Kerapu Lumpur pada petakan pertama Keramba Jaring Apung Kuala Langsa yaitu :30\% tingkat serangannya tergolong tingkat serangan Umumnya atau Infeksi biasa.

\section{Saran}

Dari hasil penelitan ini disarankan untuk dilakukannya pengamatan prevalensi dan intensitas yang berkelanjutan untuk mengetahui penularan parasit pada setiap ikan dan cara pengendalian untuk parasit Dactylogyrus sp.

\section{DAFTAR PUSTAKA}

Aloo PA. 2002. Ecological Studies of Parasites of Commercially Important Fish Species along The Kenyan Coast. Final Report. Department of Zoology. Kenyatta University. Kenya. 14p.

Anonymous. 2001. Pembudidaya dan management kesehatan ikan kerapu. SEAFDEC Aquaculture Departemen. Kelompok kerja perikanan APEC, aquaculture Department Southeast Astan Fisheries Development Center.

Bunga M. 2008. Prevalensi dan intensitas serangan parasit Diplectanum sp. pada insang ikan kerapu macan (Epinephelus fuscoguttatus, Forskall) di Keramba Jaring Apung. Jurnal Ilmu Kelautan dan Perikanan Universitas Hasanuddin. 18(3): 204-210.

Bondad, Reantaso MG, Ogawa K, Fukudome M, Wakabayashi H. 1995. Reproduction and growth of Neobenedenia girellae 
(Monogenea: Capsalidae), a skin parasite of cultured marine fishes of Japan. Fish Pathology. 30(3): 227-231.

Fernando CH, Furtado JI, Gussev AV, Kakonge SA. 1972. Methods for the study of Freshwater Fish Parasittes. Biology Series, Number Twelve. Canada: University of Waterloo. 1-44 p.

Fidyandini HP, Subekti S, Kismiyati. 2012. Identifikasi dan prevalensi ektoparasit pada ikan bandeng (Chanos chanos) yang dipelihara di keramba jaring apung UPBL Situbondo dan di Tambak Desa Gangurejo Kecamatan jabon Sidoarjo. Journal of Marine and Coastal science. 1(2): 91-112.

Haser TF, Febri SP, Nurdin MS. 2018. Pengaruh perbedaan suhu terhadap sintasan ikan bandeng (Chanos chanos Forskall). Prosiding Seminar Nasional Pertanian. 2018, Sep 5-6; Kota Langsa, Indonesia. Kota Langsa (ID): Fakultas Pertanian, Universitas Samudra. hlm 239-242.

KabataZ. 1985. Parasites and Disease of Fish Culture in the Tropics. Taylor and Francis. London. 263 p.

KurniawanA. 2012. Penyakit Akuatik. Bangka Belitung. UBB Press: 126 hal.

Made S, Fakhriyyah S, Darawelalangi A. 2017. Analisis kontribusi ekspor ikan kerapu (Ephinephelus sp.) terhadap pendapatan asli daerah (PAD) Provinsi Sulawesi Selatan. Journal of Economic and Social of Fisheries and Marine. 4(2): 126-134.

Musyafak M. 2010. Analisis tingkat prevalansi dan derajat infeksi parasite pada ikan Kerapu
Macan (Epinephelus fuscoguttatus) di lokasi budidaya Berbeda. Jurnal Kelautan. 3(1): 8290.

Ramadhan AR, Abdulgani N, Triyani N. 2012. Perbandingan Prevalansi parasit pada insang dan usus Ikan Mujair (Oreochromis niloticis) yang tertangkap di sungai Aloo dan Tambak Kedung Peluk, Kecamatan Tanggulangin, Sidoarjo. Jurnal Sains dan Seni ITS. 1(1): E36-E39.

Riko YA, Rosidah, Herman T. 2012. Intensitas dan prevalensi ektoparasit pada ikan bandeng (Chanos-chanos) dalam Kerama jaring Apung di waduk cirata kabupaten cianjur jawa barat. Universitas Padjajaran. Jurnal perikanan dan Kelautan. 3(4): 231-241.

Stasiun Karantina Ikan Kelas I Hang Nadim Batam. 2010. Laporan Pemantauan HPI dan HPIK. Stasiun Karantina Ikan Kelas I Hang Nadim Batam. Batam. 57 hal.

Subekti S, Mahasri G. 2010. Parasit dan Penyakit Ikan (Trematodiasis dan Cestodiasis). Surabaya: Fakultas Perikanan dan Kelautan Universitas Airlangga.

Williams EH, Bunkley-Williams L. 1996. Parasites of Offshore Big Game Fishes of Puerto Rico and the Western Atlantic. Puerto Rico. 383 hal.

Zafran, Roza D, Mahardika K. 2019. Prevalensi dan ektoparasit pada ikan budidaya di keramba jaring apung di teluk kapung, Buleleng, Bali. Journal of Fisheris and Marine Research. 3(1): 32-40. 